\section{Social Work \& Education}

C SW\&E, 2019

УДК 159.98:316.6(364-4)

DOI: $10.25128 / 2520-6230.19 .1 .11$

\section{Леся Шевчук,}

викладач кафедри психологопедагогічної освіти та сочіальних наук, Комунальний вищий навчальний заклад Вінницька академія неперервної освіти м. Вінниия, Україна

9lesia9@gmail.com

\author{
Тарас Шевчук, \\ кандидат медичних наук, доиент \\ кафедри загальної гігієни та \\ екології, \\ Вінницький нащіональний \\ медичний університет імені M.I. \\ Пирогова \\ м. Вінниця, Украӥна, \\ shtv@.ua
}

ORCID: 0000-0001-6644-5449

\section{Article history:}

Received: January 11, 2018

1st Revision: Febuary 21, 2019

Accepted: March 30, 2019
Шевчук, Л. \& Шевчук, Т. (2019). Використання «авсмоделі» для формування ціннісної складової когнітивного компоненту професійної ідентичності соціального педагога, який працює у системі інклюзивної освіти, Social Work and Education, Vol. 6, No. 1., pp. 106-113. DOI: 10.25128/2520-6230.19.1.11

\section{ВИКОРИСТАННЯ «АВС-МОДЕЛІ» ДЛЯ ФОРМУВАННЯ ЦІННІСНОЇ СКЛАДОВОЇ КОГНІТИВНОГО КОМПОНЕНТУ ПРОФЕСІЙНОЇ ІДЕНТИЧНОСТІ СОЦІАЛЬНОГО ПЕДАГОГА, ЯКИЙ ПРАЦЮЄ У СИСТЕМІ ІНКЛЮЗИВНОЇ ОСВІТИ}

АНОТАЦІЯ. У статті розглянуто один 3 негативних професійних чинників, що виникає під час роботи соціального педагога, а саме, труднощі у регуляції неприємних емоційних станів. Показані особливості використання АВС-моделі для впливу на ціннісну складову когнітивного компоненту професійної ідентичності соціального педагога, який працює у системі інклюзивної освіти; висвітлено сутність професійної ідентичності соціальних педагогів; підходи науковців до розуміння ціннісної системи та особливості ії змін у контексті професійної діяльності соціального педагога. Подана характеристика $\mathrm{ABC}$-моделі у інтерпретації інтегративної когнітивно-поведінкової терапії. Окреслено особливості застосування АВС-моделі для роботи 3 ціннісною складовою. Схарактеризовано схему роботи по зміні нераціональних переконань за допомогою методу Сократівського діалогу, який полягає у використанні запитань різних типів для з'ясування логічності сформованих переконань людини. Описано схему роботи 3 ціннісною складовою когнітивного компоненту професійної ідентичності соціального педагога на прикладі використанні $\mathrm{ABC}$-моделі. Обгрунтовано підходи до зміни нераціональних інтерпретацій та причин появи неприємних емоційних станів на прикладі аналізу життєвих ситуацій з соціально-психологічної практики.

Зроблено висновки про фактори, які впливають на соціального педагога, який працює в системі інклюзивної освіти та пов'язані з виникнення неприємних емоційних станів. Когнітивно-поведінкова терапія пропонує ряд методик для успішної роботи 3 такими проблемами $\mathrm{i}$ однією з найбільш ефективних є $\mathrm{ABC}$-модель. Показано як саме методика дозволяє впливати на систему цінностей соціального педагога, пов'язаних 3 причиннонаслідковими уявленнями про формування та прояв емоцій, що $\epsilon$ важливої складовою когнітивного компоненту професійної ідентичності та впливає на міру ефективності прояву професійної ідентичності у емоційно складних ситуаціях. Подальші дослідження теми можуть бути пов'язані із виявленням чинників, які стимулюють та сповільнюють напрацювання нових переконань у когнітивному компоненті професійної ідентичності.

Ключові слова: АВС-модель, інтегративна когнітивноповедінкова терапія, соціальний педагог, професійна ідентичність, інклюзивна освіта. 


\section{Вступ}

Соціальний педагог, відповідно до Положення про психологічну службу в системі освіти України, затвердженого наказом від 22 травня 2018 року № 509, здійснює соціально-психологічний супровід здобувачів освіти, які потребують піклування та бере участь у наданні допомоги дітям, які потребують посиленої педагогічної уваги чи мають особливі освітні потреби. Виконання цих завдань вимагає від соціального педагога застосування сучасних знань із психології. У процесі роботи, насамперед, можуть виникати труднощі, пов'язані 3 появою неприємних емоційних станів, оскільки робота у системі інклюзивної освіти може створювати непередбачувані ситуації емоційної напруги. Вони можуть заважати соціальному педагогу адекватно діяти в межах своєї професійної ідентичності.

За даними Н. Tajfel та J. Turner (1986, с. 20), основою професійної ідентичності є три складових елементи: когнітивний, емоційний і поведінковий. У когнітивному компоненті ядро складають когнітивні схеми, набуті фахові знання, що формуються у тісному зв'язку із ціннісною системою індивіда: нормами, правилами, установками. Ціннісна система, в свою чергу, відображає систему базових потреб людини, а емоційний компонент відображає міру функціональності, задоволеності чи незадоволеності цих потреб. Емоційний компонент впливає на поведінковий, який і $є$ підсумком прояви професійної ідентичності. По це ж говорить Лідія Шнайдер (Шнейдер, 2004, с.182) у своєму дослідженні професійної ідентичності, підкреслюючи, що «цінності створюють ідентичність» (Шнейдер, 2004, с.27).

Структура професійної ідентичності формується у процесі взаємодії соціальної ідентифікації, соціальної категоризації, емоційного зараження, когнітивної та емоційної переробки. У результаті набувається і структурується розуміння професійної сутності людини та іiі місця у професійній групі (Tajfel, Turner, 1986, с. 20). Соціальний педагог,набуваючи професійну ідентичність, проходить через усі ці процеси. Те, на скільки компетентно буде він на практиці застосовувати фахові вміння, великою мірою залежить від уміння справлятись із неприємними емоціями у робочих ситуаціях. Такі уміння закладаються на рівні цінностей у структурі когнітивного компоненту професійної ідентичності.

За дослідженнями В. Агєєва, ціннісна система є основним регулятором поведінки і самовизначення у житті людини (Агеев, 1983, с. 144). Натомість, процес ідентифікації цінностей значною мірою буде залежати від атрибуції особистості, що може бути екстернальною та інтернальною. Слід врахувати, що когнітивна орієнтація екстернального типу особистості буде спрямована на пошук зовнішніх ознак у системі цінностей, тобто таких, до яких сама людина докладає менше зусиль, в інтернальній атрибуції навпаки - регулятором поведінки є орієнтація на власні зусилля і переконання. Зовнішні регулятори виступають як зовнішні причини соціальної поведінки особистості, а внутрішні регулятори виконують функцію тієї призми, через межі якої заломлюється дія цих зовнішніх детермінантів (Маслоу, 2019). Тобто, якщо соціальний педагог має когнітивну орієнтацію екстернального типу, він буде схильним піддаватись зовнішнім чинникам у поясненні причин своїх емоційних станів. За результатами нашого опитування, 90\% соціальних працівників має такий тип когнітивної орієнтації. Інтернальний тип когнітивної орієнтації сприяє тому, що людина бачить причинами власних емоційних станів систему своїх переконань та цінностей. 
Виходячи з психології особистості Е. Еріксона шляхом переосмислення цілей, цінностей, переконань, прийняття рішень відбувається самовизначення особистості. Тому прийняття професійних цінностей, ідеалів і норм створює конструкт, який є основою професійної ідентичності (Эриксон, 1996, с. 344).

Теорія М. Яницького про динамічність системи ціннісних орієнтацій особистості, підтверджує, що в основі регуляції соціальної поведінки та професійної діяльності людини знаходиться система її ціннісних орієнтацій, що $є$ складним і динамічним утворенням, інтегрує різні підходи до пояснення закономірностей іï внутрішньої організації та динаміки (Яницкий, 2000, с. 204). Тобто, науковці на практиці доводять, що система професійних цінностей соціального педагога $\epsilon$ динамічним конструктом i може піддаватись коригуванню.

Когнітивно-поведінкова терапія для роботи 3 цінностями та переконаннями людини пропонує один із найефективніших прийомів, а саме АВС-модель. Особливу увагу слід звернути на роботи німецьких фахівців 3 інтегративної когнітивно-поведінкової терапії К. Борна, Х. Борн та Г. Мюллера, які детально описують методику застосування АВС-моделі. ІЇ стислий зміст полягає у тому, що наші відчуття та емоції $\epsilon$ результатом наших оцінок, які базуються на життєвому досвіді. Самі ж оцінки утворюються у результаті взаємодії наших базових переконань та цінностей (Born, 2015, с. 48).

Також, дуже детально та розгорнуто подають схему та аналіз використання АВС-моделі для роботи з нераціональними цінностями та переконаннями фахівці Оксвордського центру когнітивно-поведінкової терапії Х. Кеннерли, Д. Вестбрук та Дж. Кірк (Westbrook, 2011).

Отже, метою статті та основним їі завданням $є$ поширення знань та практики застосування АВС-моделі для формування ціннісної складової когнітивного компоненту професійної ідентичності серед соціальних педагогів, що працюють в системі інклюзивної освіти.

\section{Методологія дослідження}

Окреслені мета та завдання дослідження потребують використання ряду методів дослідження. Передусім, був здійснений інформаційний пошук у зарубіжних та вітчизняних наукових виданнях щодо зазначеної проблеми та застосовані загальнонаукові методи аналізу, синтезу, порівняння та узагальнення отриманих результатів. Емпіричний метод здійснювався у процесі власної психологічної практики на протязі останніх 5 років i показав високу ефективність АВС-моделі.

\section{Основна частина}

Відповідно до інтегративного когнітивно-поведінкового підходу X. Штавемана (Stavemann, 2014) та К. Борна (Born, 2015) АВС-модель допомагає людині усвідомити першоджерела появи неприємних емоцій, скоригувати власну систему цінностей та переконань та набути нових умінь для управління неприємними емоційними станами. Нами було запропоновано соціальним педагогам розгорнуту інформацію що до теоретичних та практичних аспектів застосування АВС-моделі.

На першому етапі завданням було усвідомити когнітивну та емоційну складові, для розуміння процесу оцінювання і появи почуттів. «Ми поділяємо все автоматично на добре і погано і на правильно і неправильно. Результатом чого $є$ наші почуття. Оцінки завжди суб'єктивні, проте цілеспрямовані. Ми можемо зробити оцінки відносними і послабити їх тим, що ми замість слів добре, погано, 
правильно, неправильно будемо вживати слова сприятливо або несприятливо використовуючи їх свідомо у співвідношенні з цілями:

- «Мою чи твою поведінку я знаходжу сприятливою чи несприятливою по відношенню до моєї мети!»

- «Я зробив помилку - це несприятливо по відношенню до моєї мети.»

- «Твої недостатні вміння несприятливі не самі по собі, а тільки по відношенню до твоїх цілей».

Формулювання понять сприятливо чи несприятливо ми, зазвичай, не співвідносимо з виражено негативними або позитивними оцінками, що, у свою чергу, допомагає відчувати менш виражені емоції. Це проста зміна стилю мислення приносить великий виграш у сенсі зменшення негативних емоцій (Борн, 2011, с. 13).

Нажаль, більшість людей, в тому числі соціальних педагогів (90\% за результатами нашого опитування), мають сформовану звичку реагувати на зовнішні обставини категорично і вважати саме ці обставини причинами своїх негативних емоційних станів.

На наступному етапі соціальним педагогам потрібно було оцінити дії вчителя та виявити, що стало причиною неприємних емоцій. Ситуації стосувались здобувачів освітнього процесу 3 особливими потребами та соціально-психологічного супроводу таких осіб. Приклад однієї з ситуацій: «У класі навчається Коля Т. Сім'я у нього неблагополучна. У хлопчика проблема 3 концентрацією уваги, моральною регуляцією, спостерігається відставання від однолітків у інтелектуальному розвитку. Під час заняття може по кілька разів вставати, ходити по класу, видаючи різні звуки, імітуючи тварин. Педагога така поведінка дратує, він показує своє роздратування, підвищує голос на учня.» Коментар до ситуації: «Педагог застосовує до хлопчика ті ж когнітивні схеми (або, іншими словами, правила), що і до інших дітей: «всі учні повинні слухати, виконувати усі завдання, бути уважними».

Аналізуючи ситуацію, потрібно звернути увагу на такі аспекти. Правила (цінності професійної ідентичності) педагога порушуються. (Учень не слухає, не виконує завдання, не є уважним). Їх порушення веде до того, що у педагога страждає цілий комплекс потреб: він не може виконувати свої професійні обов'язки і отримувати задоволення від виконаної роботи (почуття власної важливості не задоволено і складно контролювати ситуацію). Як наслідок, включаються емоції, соціальний педагог дратується, у його поведінкових реакціях з'являється підвищення тону голосу, різкість рухів, йому складно стримувати обурення.

Емоційна сфера педагога потрапляє у ситуацію невизначеності. I ця невизначеність може створювати дисбаланс і дезорієнтацію в професійних цінностях і цілях.

Під час нашого опитування, яке проводилось на курсах підвищення кваліфікації соціальних педагогів та семінарах для соціальних педагогів 32011 по 2016 рр., ми задавали питання до різних подібних ситуацій: «Що стало причиною емоції педагога?» 90\% респондентів із близько 300 опитаних відповідали, що ситуація. Після ознайомлення із АВС-моделлю, роботи методом Сократівського діалогу, на те ж саме питання 99\% учасників опитування давали відповідь, що причиною емоцій педагога стали його оцінка ситуації, сформована на підставі цінностей та глибинних переконань. 
Яким чином до цього прийти? Потрібно скористатися методом «АВСмоделі». Інтегративна когнітивно-поведінкова терапія пропонує використовувати цю когнітивну техніку у подібних випадках.

Послідовність роботи для пояснення «АВС-моделі»:

Питання: «Що стало причиною роздратування педагога?»

Відповідь 90\% респондентів: «Поведінка учня».

Питання: «Який тоді можете зробити висновок щодо емоцій? Результатом чого вони $\epsilon ? »$

Відповідь: «Емоції - результат ситуації».

Питання: «Тобто, щоб виникла емоція - потрібна ситуація?»

Відповідь: «Так».

Питання: «Чи означає це, що коли люди присутні в одній ситуації - у них повинна бути однакова емоція?»

Тут уже найчастіше відповідають, що це не так, люди по-різному сприймають ситуацію і дають їй різну оцінку. І ось цей висновок дуже важливий. Він звертає увагу соціального педагога на важливість саме суб'єктивної оцінки ситуації. Адже не всі педагоги, які опинились у такій ситуації реагують однаково, що пов'язано з різним оціночним підходом. Тому, виникає наступне важливе питання: «Так результатом чого є наші емоції?». «Наші емоції результат наших оцінок, оцінки формуються на підставі глибинних переконань думками». Тобто, оцінка відбувається на підставі ціннісної системи людини. Виходячи із цього - потрібно працювати 3 думками (когнітивна складова) i цінностями.

Когнітивні теорії мотивації будь-яку дію розглядають як таку, яка чимось мотивована, що, у свою чергу, є вибором певної форми поведінки. І цей вибір здійснюється на підставі аналізу фізіологічного стану, емоцій, думок, присутністю інших.

Для роботи 3 когнітивною складовою проводиться реконструкція негативних когнітивних інтерпретацій, іншими словами, пошук нераціональних ідентифікаційних схем. Вплив на емоційний компонент ідентичності відбувається через усвідомлення та відпрацювання цільових і нецільових емоційних станів. Інформація про особливості переживань емоцій та емоційних станів допомагає людині краще розуміти причину їх виникнення та здійснювати самокорекцію.

Для набуття нових когнітивних моделей (ідентифікаційних схем) потрібне також усвідомлення самооцінки, напрацювання iï коректності та адекватності. Вироблення навичок самоконтролю через напрацювання нових схем поведінки, через раціональність мислення сприяє зникненню неприємних спогадів та переживань.

Пошук та відпрацювання ситуацій, у яких виникали неприємні емоції та розбір складових елементів нераціональних ідентифікаційних схем, переконань допомагають усвідомити пережиті ситуації та прийняти їх перебіг, спираючись на іншу раціональну оцінку. Інтегрованість підходу когнітивно-поведінкового напрямку сприяє залученню до роботи кращого досвіду різних психологічних та психотерапевтичних шкіл, що спрощує роботу та сприяє кращому досягненню результатів.

\section{Висновки}

На соціального педагога, який працює в системі інклюзивної освіти впливають цілий ряд негативних факторів, що пов'язані 3 виникнення неприємних емоційних станів. Когнітивно-поведінкова терапія пропонує ряд 
технік для успішної роботи 3 такими проблемами і однією 3 найбільш ефективних слід вважати АВС-модель. Зазначена методика дозволяє впливати на систему цінностей соціального педагога, що є важливої складовою когнітивного компоненту професійної ідентичності. Використовуючи зазначені психологічні прийоми, педагог може більш успішно контролювати та регулювати свої неприємні емоції, що дозволить йому сформувати адекватний рівень професійної ідентичності та, як наслідок, високу ступінь адаптації до професійного середовища. Подальші наукові пошуки можуть бути спрямовані у напрямку виявлення факторів, які покращують та сповільнюють напрацювання нових раціональних цінностей у когнітивному компоненті соціальної ідентичності соціального педагога.

\section{Лiтература}

Агеев, В. С. (1983). Психология межгрупповых отношений: монография; МГУ им. М. В. Ломоносова. М. : Изд-во МГУ. 144.

Борн, К. (2011). Решение проблемы самооценки или „комплекса (не) полноценности“: Перевод и дополнения Алексея Рохленко. Хесен: Institut für integrative Verhaltenstherapie. 22.

Маслоу, А. (2019). Дальние пределы человеческой психіки; перевела с английского О. Чекчурина. Санкт-Петербург Ги др.]: Питер. 444.

Міністерство освіти і науки України. (2005). Наказ Про затвердження Положення про психологічну службу у системі освіти України ГЕлектронний peсурс]. Режим доступу до ресурсу: https://zakon.rada.gov.ua/laws/show/z0885-18.

Шнейдер, Л. Б. (2004). Профессиональная идентичность: теория, эксперимент, тренинг: учеб. пособие ; Рос. акад. образования, Моск. психол.-социал. ин-т. М.: Изд-во Моск. психол.-соц. ин-та ; Воронеж : НПО "МОДЭК". 594.

Эриксон, Э. (1996). Идентичность: юность и кризис ; пер. А. Д. Андреева [и др.] ; общ. ред. и предисл. А. В. Толстых. М.: Изд. группа "Прогресс". 344.

Яницкий, М. С. (2000). Ценностные ориентации личности как динамическая система. Кемерово: Кузбассвузиздат, 204.

Stavemann, H. H. (2014). Integrative KVT: Die Therapie emotionaler Turbulenzen. Mit Arbeitsmaterial zum Download.

Stavemann, H. H. (2010). Im Gefühlsdschungel. Emotionale Krisen verstehen und bewältigen. Beltz Verlag (Weinheim, Basel). 2., vollst. überarbeitete Auflage. 367.

Stets, J. E., Burke, P. J. (2000). Identity theory and social identity theory. Social psychology quarterly. 224-237.

Tajfel, H., Turner, J. (1986). The social identity theory of intergroup behavior. Psychology of inter group relations. Chicago: Nelson-Hall, 7-24.

Westbrook, D., Kennerley, H., Kirk, J. (2011). An introduction to cognitive behaviour therapy: Skills and applications. Sage. 


\section{THE USE OF "ABC-MODEL" FOR FORMING A VALUE COMPOSITION OF COGNITIVE COMPONENT OF PROFESSIONAL IDENTITY OF A SOCIAL PEDAGOGUE WORKING IN INCLUSIVE EDUCATION SYSTEM}

Lesya Shevchuk, Teacher of the Department of Psychological, Pedagogical Education and Social Sciences, Vinnytsia Academy of Continuing Education, Vinnytsya,Ukraine9lesia9@gmail.com

Taras Shevchuk, PhD in Medical Sciences, Associate professor of the department of general hygiene and ecology, Vinnytsia National Medical University named after M.I. Pyrogov, Vinnytsia, Ukraine, shtv@i.ua

Abstracts.The article deals with the peculiarities of using "ABC-model" to influence the value component of the professional identity of teachers working in inclusive education system. Change in cognitive assessments that the teacher gives to a complex situation leads to a decrease in the intensity of emotional experience.

The article reveals the peculiarities of the professional activity of the social pedagogue who may cause difficulties in the regulation of unpleasant emotional states. The peculiarities of the use of the ABC-model for the influence on the value component of the cognitive part of the professional identity of the social pedagogue working in the system of inclusive education are explained; the essence of the professional identity of social educators is highlighted; the approaches of different scholars to understanding the value system and the peculiarities of its changes in the context of the professional activities of the social teacher. The characteristic of the ABC model in the interpretation of integrative cognitive behavioral therapy is proposed: sensations and emotions are the result of evaluations that are the product of the deep beliefs and values of a personal values system. The features of the use of the ABC-model for working with the value component are outlined. The scheme of work on changing irrational beliefs with the help of the Socratic Dialogue method is described, which consists in using different types of questions to ascertain the logic of the person's prevailing beliefs. The scheme of work with the value component of the cognitive component of the professional identity of a social teacher is described on the example of the use of the ABC model. It is substantiated how it is possible to approach the change of irrational interpretations and causes of the appearance of unpleasant emotional states on the example of analysis of life situations from social and psychological practice.

Conclusions are made on the factors influencing the social teacher who works in the system of inclusive education and associated with the emergence of unpleasant emotional states. Integrative cognitive-behavioral therapy offers a number of techniques for successful work with such problems and one of the most effective is the $A B C$ model. It is shown how the technique allows to influence the system of values of the social teacher related to the causal concepts of the formation and manifestation of emotions, which is an important component of the cognitive part of the professional identity and influences the effectiveness of the manifestation of professional identity in emotionally difficult situations. Using these psychological techniques, the teacher can form new rational beliefs and improve his level of adaptation to complex professional situations. Further research of the topic may be related to the identification of factors that stimulate or slow down the development of new beliefs in the cognitive component of professional identity. 
Key words: ABC model; integrative cognitive-behavioral therapy; social pedagogue; professional identity; inclusive education.

\section{References}

Ageev, V. S. (1983). Psychology of intergroup relations: monograph / V.S. Ageev; Moscow State University M. V. Lomonosov. M.: Publishing House of Moscow State University, 144. (rus).

Born, K. (2011). Solving the problem of self-esteem or the "complex of (incomplete) usefulness": Translation and additions by Alexei Rokhlenko. Hesen: Institut für integrative Verhaltenstherapie. 22. (rus).

Erickson, E. (1996). Identity: youth and crisis; total ed. and foreword A. V. Tolstoy. M.: Ed. group "Progress". 344. (rus).

Ministry of Education and Science of Ukraine. (2005). Ordinance On Approval of the Regulations on the Psychological Service in the System of Education of Ukraine [Electronic resource] / Ministry of Education and Science of Ukraine. Access to the resource: https://zakon.rada.gov.ua/laws/show/z0885-18. (ukr).

Schneider, L. B. (2004). Professional Identity: Theory, Experiment, Training: Studies. allowance; Grew up Acad. Education, Mosk. psikhol.-sotsial. in-t. M.: Publishing House of Moscow. psikhol.-soc. in-that; Voronezh: NPO MODEK. 594. (rus).

Stavemann, H. H. (2014). Integrative CBT: the therapy of emotional turbulence. With work material for download.

Stavemann, H. H. (2010). In the emotional jungle. Understand and overcome emotional crises. 2nd, completely revised edition. 367.

Stets, J. E., Burke, P. J. (2000). Identity theory and social identity theory. Social psychology quarterly. 224-237.

Tajfel, H., Turner, J. (1986). The social identity theory of intergroup behavior. Psychology of inter group relations. Chicago: Nelson-Hall, 7-24.

Maslow, A. (2019). The Far Limits of the Human Psyche; translated from English by O. Chekchurin]. St. Petersburg [and others]: Peter. 444. (rus).

Westbrook, D., Kennerley, H., Kirk, J. (2011). An introduction to cognitive behaviour therapy: Skills and applications. Sage.

Yanitsky, M. S. (2000). Value orientation of the person as a dynamic system. Kemerovo: Kuzbassvuzuzdat. 204. (rus). 
